\title{
Trade Patterns of Bangladesh with India and China: An Empirical Evidence of the PPP Theory
}

\author{
Kazi Ashraful Alam \\ Assistant Professor \\ School of Business \\ Presidency University \\ Dhaka, Bangladesh \\ Email: Kashraf@presidency.edu.bd \\ Md. Gazi Salah Uddin \\ Lecturer \\ School of Business \\ Presidency University \\ Dhaka, Bangladesh \\ Email: salahuddin@presidency.edu.bd \\ Md. Mahmudul Alam \\ Head of Operational Analysis \\ Customer Relationship Management (CRM) \\ Segments, Marketing Division \\ Grameenphone Ltd. \\ Dhaka, Bangladesh \\ Email: rony000@gmail.com
}

\section{Citation Reference:}

Alam, K.A., Uddin, M.G.S., and Alam, M.M., Malakar, B. 2009. Trade Patterns of Bangladesh with India and China: An Empirical Evidence of the PPP Theory, Journal of Regional Economic Studies, Vol. 2, pp. 26-34. (Publisher- University of North Bengal, India)

This is a pre-publication copy.

The published article is copyrighted by the publisher of the journal. 


\title{
Trade Patterns of Bangladesh with India and China: An Empirical Evidence of the PPP Theory
}

\author{
Kazi Ashraful Alam ${ }^{1}$ \\ Md. Gazi Salah Uddin ${ }^{2}$ \\ Md. Mahmudul Alam ${ }^{3}$
}

\begin{abstract}
The paper examines the existence of the Purchasing Power Parity (PPP) theory for both Bangladesh and its two important trading partners- India and China. The PPP theory is an attempt to explain and perhaps more importantly measure statistically, the equilibrium rate of exchange and its variation by means of the price levels and their variations in different countries. The main purpose of the study is to get a comparative picture of trade balance between Bangladesh (home country) and two major trade partners, i.e. India and China (foreign countries) over a given period of time by using the PPP. The empirical results of the study provides an explanation of how relative inflation rates (changes of price level) between two countries can influence an exchange rate and also critically focuses on the degree of deviation between countries which may help to draw a forecast long-run movements in exchange rates. Finally the results also specify about the trade patterns among the countries and fairly conclude the efficient and beneficial trade partner in respect of Bangladesh with India and China.
\end{abstract}

Key words: Purchasing Power Parity, Price Level, Exchange Rates, Bilateral Trade Balance

\section{Introduction}

The modern theory, like the classical theory of trade, considers the existence of relative differences in the costs and prices of those commodities which are traded as the immediate cause for trade between countries. The modern theory presents an analysis of the causes responsible for differences in the relative prices of commodities which inter into trade. Foreign trade, according to modern theory, springs from the conditions of production, which differ from country to country and the immediate cause of international trade is the differences in relative prices of commodities in the two countries. Among the factors which cause differences in commodity prices as between countries, factor endowments of different countries (i.e., differences in the relative supply of different factors) exhibit great variations.

Economic activity is globally unifies today to an unprecedented degree. Changes in one nation's economy are rapidly transmitted to that nation's trading partners. These fluctuations in economic activity are reflected, almost immediately, in fluctuations in

\footnotetext{
${ }^{1}$ Kazi Ashraful Alam, Assistant Professor, School of Business at Presidency University, Dhaka, Bangladesh.

2. Md. Gazi Salah Uddin, Lecturer, School of Business at Presidency University, Dhaka, Bangladesh.

${ }^{3}$. Md. Mahmudul Alam, Head of Operational Analysis, Customer Relationship Management, Segments, Marketing Division, Grameenphone Ltd., Dhaka, Bangladesh.
} 
currency values. An exchange rate is simply, the price of one nation's currency in terms of another currency. As the supply and demand schedules for a currency change over time, the equilibrium exchange will also change. Some of the factors that influence currency supply and demand are inflation rates, interest rates, economic growth and political and economic risks.

The purchasing-power-parity (PPP) theory is an attempt to explain and perhaps more importantly measure statistically, the equilibrium rate of exchange and its variation by means of the price levels and their variations in different countries. This theory, which is usually associated with the Swedish economist Gustav Cassel (1918), is based on the simple idea that a certain amount of money should purchase the same representative bundle of commodities in different countries-hence Cassel's term purchasing power parity. In its absolute version, purchasing-power-parity states that price levels should be equal world wide when expressed in a common currency. However absolute PPP ignores the effects on free trade of transaction costs, tariffs, quotas and other restrictions and product differentiations. The relative version of purchasing-power-parity, which is used more commonly now, states that the exchange rate between the home currency and foreign currency will adjust to reflect changes in the price levels of the two countries.

The present study aims at depicting a comparative picture of trade balance between Bangladesh (home country) and two major trade partners, i.e. India and China (foreign countries) over a given period of time. The relationship between these countries is tested by using the PPP (Purchasing Power Parity) theory which provides an explanation of how relative inflation rates (changes of price level) between two countries can influence an exchange rate. The study also critically focuses on the degree of deviation between countries which may help to draw a forecast long-run movements in exchange rates and looks about the trade patterns among the countries and fairly concludes the efficient and beneficial trade partner in respect of Bangladesh with India and China.

\section{Bangladesh Trade Status with India and China:}

Both Bangladesh and India are two major SAARC countries and have a long historical trade relationship. As far as trade relation is concerned, India is the second largest trade partner of Bangladesh, just after USA in 2003, but recently China has emerged as the largest source of import for Bangladesh replacing India for the first time in 2006.

Bangladeshi import from China amounted to 13751.2 million taka in 2005-2006 fiscal against 12416 million taka import from India during the same period. Bangladesh's import from India was 12333.9 million taka in the 2004-05 fiscal while the amount was 69404.10 million taka from China during the same period. India exported goods worth 9,420 crore taka in the 200304 financial years while China exported products worth 6,676 crore taka to Bangladesh in the same fiscal. India was the top source of Bangladesh's import in the 2002-2003 fiscal exporting goods worth 7,845.35 crore taka against 4,521 crore taka from China.

Another reason of increasing peoples' interest about the trade pattern is the geographical distance India shares three of its border with Bangladesh and none by China and also regional politics. China is also the largest supplier of military hardware to Bangladesh. Also political view influence both countries trade i.e. in the $30^{\text {th }}$ anniversary of relationship, 2005 was declared as 'China-Bangladesh Friendship Year' when both countries agreed to allowing the joint economic and trade commission to develop and expand potential bilateral trade. Kumar 
(2006) said, "When south Asia is thinking to integrate economically under the SAFTA trade should have been increasing among these countries. But when a country lying outside the region emerges as the largest trade partner replacing the biggest member of south Asia this highlights the fact that there is something amiss with the trade and foreign policies of these countries." After all, if the Chinese long-term intention were to compete with India as an Asian power, or challenge the importance of India, the best way to combat this would be face the challenge that China resents. (Aneja, 2006)

Bangladeshi importers are interested in China because it is offering goods with a wide price range, easy trade procedures, many duty free goods, smaller timing of shipment etc. China usually sends its products to Bangladesh within 25 days on an average by completing all the formalities while import from India takes 35 days. Bangladeshi importer also think, Chinese products are cheap compared to the same quality product of India, so that they import same product from China which was imported from India such as, food stuff, plastic goods, rubber goods, wooden products, raw hides, pulp, papers, electrical machinery and equipment and parts thereof, sound recorders and reproducers, television accessories of electronics articles, boilers, machinery and mechanical appliances, parts thereof, Cotton, yarn/thread and cotton fabrics etc.

$$
<\text { Table- } 1>>
$$

These figures is the reason of aggravate to observe the trade relationship between Bangladesh and India and also between Bangladesh and China. In what extend the exchange rate and the inflation rate moved and their impact on bilateral trade issues between countries within a specific time period is also reviewed.

\section{Literature Review:}

The essence of PPP is that the price levels in the respective countries influence the exchange rate between two currencies. The theory is based on the basis of the law of one price (LOP), which implies that once converted to a common currency, the same good should sell for the same price in different countries. As such, the nominal exchange rate between any two countries should equate their price ratio (Balassa, 1964). In reality, discrepancies between the nominal exchange rate and price ratio are observed in the short run. However, the accumulated discrepancies may build up arbitrage profit, which will eventually be arbitraged away. Thus, in the long run, arbitrage profit equals zero, and nominal exchange rate would be restored to the equilibrium value as determined by the price ratio.

Chacholiades (1990) states that exchange rate movements are commonly measured by the percentage change in their values over a specified period. The key economic factors that can influence exchange rate movements through their effects on demand and supply conditions are relative inflation rates, interest rates, and income levels as well as governments controls. Purchasing Power Parity (PPP) theory specifies a precise relationship between relative inflation rates of two countries and their exchange rate. This theory suggests that the equilibrium exchange rate will adjust by the same magnitude as the differential in inflation rates between two countries.

Much research has been conducted to test whether PPP exists. Studies by Adler and Dumas (1983), Mishkin (1984), and Abuaf and Jorion (1990) found evidence of significant deviations from PPP that persisted for lengthy periods. A related study by Adler and Lahman 
(1983) provided evidence against PPP even over the long term. Applied to industrialized countries during the floating exchange era, many studies failed to reject the hypothesis that real exchange rates follow a random walk (Rogoff, 1996). Hakkio (1986), however, found that when an exchange rate deviated far from the value that would be expected according to PPP, it moved toward that value. Although the relationship between inflation differentials and exchange rates is not perfect even in the long run, it supports the use of inflation differentials to forecast long run movements in exchange rates.

\section{Data, Model and Methodology:}

In this study, yearly data for 1978-2000 is taken from International Financial Statistics CDRom (January 2005) and from the year of 2000-2005 data is taken from the published data book of International Financial Statistics. Bilateral Exchange rates between any two countries are computed from bilateral exchange rates of each of these countries with the US. Real exchange rate series has been constructed with the GDP Deflator series and the exchange rate series for the price of US dollars in respective currencies for the year of 1987 to 2005. CPI does not cover the prices of all products but only the consumer goods where GDP Deflator considers all the prices in the economy. Bangladesh trades not only consumer goods but also military and other products with partners' countries so that GDP deflator data is used instead of CPI data. For statistical analysis the output is generated by using PC Gives-10+ updated software.

The Law of One Price can be extended to a price index by taking a weighted average of the price of each good. Therefore, absolute Purchasing power parity (APPP) is:

$$
\mathrm{P}=\mathrm{EP}^{*}, \text { or } \mathrm{E}=\mathrm{P} / \mathrm{P}^{*}
$$

Where $\mathrm{P}\left(\mathrm{P}^{*}\right)$ is the domestic (foreign) price level, $\mathrm{E}$ is the exchange rate. But APPP (absolute purchasing power parity) has some drawbacks. Firstly, the basket of goods used to measure the price index in each country should be identical in each country. If there are no trade barriers, transportation costs of imperfect competition, and the basket of goods and their relative weights are identical in both countries, the rate of change in the exchange rate should equal to the rate of change in the price level ratio. The Relative PPP said the rate of changes in the price of products should be similar when measured in a common currency as long as transportation cost and trade barriers are unchanged. Relative PPP might be valid, even if absolute PPP is not. Here relative PPP is tasted for both China and India with Bangladesh. The model is:

$$
\ln \mathrm{E}_{\mathrm{t}}=\alpha+\beta_{1} \ln \mathrm{P}_{\mathrm{t}}+\beta_{2} \ln \mathrm{P}_{\mathrm{t}}^{*}+\mathrm{e}_{\mathrm{t}}
$$

Where $\mathrm{P}_{\mathrm{t}}$ is the domestic (Bangladesh) price in period $\mathrm{t}$, measured in Taka, $\mathrm{P}_{\mathrm{t}} *$ is the foreign price (separately for India and China) in period $t$ measured in foreign currency, and $E_{t}$ is the domestic nominal exchange rate (Bangladesh currency to India or China currency) in period

t. For comparison, two coefficients, which represent the price relations with exchange rate for domestic and foreign price, are calculated in one single coefficient (Eq-3) that represents combined price impacts on bilateral exchange rate.

$$
\begin{aligned}
& \ln \mathrm{E}_{\mathrm{t}}=\alpha+\beta\left\{\ln \mathrm{P}_{\mathrm{t}}-\ln \mathrm{P}_{\mathrm{t}}^{*}\right\}+\mathrm{e}_{\mathrm{t}} \\
& \text { Bilateral Real Exchange Rate }\left(\mathrm{BRER}_{\mathrm{t}}\right)=\mathrm{P}_{\mathrm{t}} /\left(\mathrm{E}_{\mathrm{t}} \mathrm{P}_{\mathrm{t}}^{*}\right)
\end{aligned}
$$


If the increase in domestic process is faster as compared to that of the foreign country, then the exchange rate will depreciate. This implies that in response to any shock or disturbance, the real exchange rate must return to its PPP defined level. This is a useful interpretation as it can be empirically testable (Eq-4). Rejection of unit root hypothesis of Bilateral Real Exchange rate (BRER) indicates mean reversion in real exchange rates.

\section{Result Analysis:}

The statistical result of PPP for Bangladesh with India shows that price of both countries has significant impacts on bilateral exchange rate. In case of determining separate price effect on bilateral exchange rate (Eq-2), PPP holds when coefficient value of home price is 1 and coefficient value of foreign price is -1 . Here the output of Eq-2 shows, the price coefficient of home country (Bangladesh) is .604 and the price coefficient of foreign country (India) is 0.911, which means PPP does not hold for Bangladesh and India. In addition, the statistical result of PPP for Bangladesh with China shows that the price of foreign country (China) has no significant impacts on bilateral exchange rate and the price of home country (Bangladesh) has opposite behavior that PPP warranted.

$$
<<\text { Table- } 2>>
$$

The statistical output for Bilateral Real Exchange Rate (BRER $)$ of Bangladesh with India and Bangladesh with China (Eq-4) show that the null hypothesis of a unit root is not rejected. This means that these real exchange rate indices are nonstationary which implies that PPP does not hold for any of these countries of India and China with Bangladesh.

$$
<<\text { Table- } 3>>
$$

The statistical output shows combined price has a significant impact on bilateral exchange rate (Eq-3) for Bangladesh with India. If the coefficient of combined price value is 1 than PPP hold, and if the coefficient is less than 1 then domestic currency is depreciated in against of foreign currency leads to strengthening the competitiveness of home country's industries in the world market and vice versa. Here the coefficient of combined price of Bangladesh and India is 1.605, which means Bangladeshi currency is appreciated by more than is warranted by PPP, weakening the competitiveness of Bangladesh industries in the India market. . The combined price of Bangladesh with China has no significant impact on bilateral exchange rate $(\mathrm{Eq}-3)$.

$$
\begin{gathered}
<<\text { Table- } 4>> \\
<<\text { Graphs- } 1,2>>
\end{gathered}
$$

In case of graphical representation of PPP, the $45^{0}$ line is the PPP line. Each foreign country (India/China) will exhibit an inflation differential relative to the home country (Bangladesh), which can be compared to the exchange rate change during the period concern. Thus a point can be plotted on a graph for each foreign country analyzed. And if the points deviated significantly from the PPP line, then the exchange rates are not responding to the inflation differentials in accordance with PPP theory. 


\section{Conclusion:}

Bangladesh, as a developing country, is involved in trading with many other developing and developed countries. But the current trade volume of Bangladesh between China and India is a significant issue in recent period. Purchasing Power Parity (PPP) theory specifies a precise relationship between relative inflation rates of these countries and their exchange rates. This theory suggests that the equilibrium exchange rate will adjust by the same magnitude as the differential in inflation rates between two countries. However, the statistical result of PPP for Bangladesh with India and China shows that the price of foreign country (India or China) has no significant impacts on bilateral exchange rate and the price of home country (Bangladesh) has opposite behavior that PPP warranted. There are many reason of PPP does not hold for Bangladesh with its partner countries- India and China. We consider some of the reasons PPP may not hold, such as, transportation costs and trade restrictions, costs of non-tradable inputs, perfect information etc. But it is mostly remarkable that though PPP does not hold for India, the price changes of India has significant impact on bilateral exchange rate with Bangladesh, which is not experienced for China. Changes of price level in China have no impact on its bilateral exchange rate with Bangladesh but still the trade volume of Bangladesh is increasing with China rather than India. As per the theory, if this trade pattern will continue, Bangladesh will become looser in trade but the reality may differ.

\section{Referecnes:}

Abuaf, Niso, and Philippe Jorion (1990), "Purchasing Power in the Long Run," Journal of Finance, vol.XLV, pp.157-174.

Adler, Michael and Bruce Lehman (1983), "Deviation from purchasing power parity in the long run," Journal of Finance, vol.39, pp.1471-1487.

Adler, M. and Berbard Dumas (1983), "International Portfolio Choice and Corporate Finance: A synthesis,” Journal of Finance, vol.38, pp.925-984, June.

Aneja, Urvashi (2006), "China-Bangladesh Relations: An Emerging Strategic Partnership?," IPCS Special Report, Institute of Peace and Conflict Studies, New Delhi, November. Available at <http://www.ipcs.org/countSpecialReport.jsp?x=33.>

Balassa, B. (1964), "The Purchasing-Power Parity Doctrine: A Reappraisal," Journal of Political Economy, vol. 72(6), pp.584-596, December.

Bangladesh Bank (2004-2005, 2005-2006), Import Payments (annual), Department of Public Relations \& Publication, Dhaka, Bangladesh.

Cassel, Gustav (1918), "Abnormal deviations in international exchanges," Economic Journal, vol.28, pp.413-415, December.

Chacholiades, Miltiades (1990), International Economics, International Ed., McGraw-Hill Book Co.: Singapore.

Hakkio, Craig S. (1986), "Interest rates and Exchange rates-What Is the Relationship?," Economic Review, Federal Reserve bank of Kansas City, pp.33-43, November. 
Hassan, M. K. (2001), "Is SAARC a Viable Economic Block? Evidence from Gravity Model," Journal of Asian Economics, vol. 12(2), pp.263-290.

Cookson, Forrest E., A. K. M. Shamsul Alam (2002), Towards Greater Sub-regional Economic Cooperation: Limitation, Obstacles, and Benefits/edited, chapter 10, pp.349-401, University Press: Dhaka.

International Financial Statistics (2005), CD-ROM annual subscription and IMF Statistics Department, vol. LX, No.2.

Kumar, Anand (2006), "China Replaces India as largest Exporter to Bangladesh," South Asia Analysis group, Paper No. 1717, $3^{\text {rd }}$ March. Available at <http://www.saag.org/\%5Cpapers18\%5Cpaper1717.html>

Madaan, D. K. (1996), Indo-Bangladesh Economic Relations and SAARC, ,Deep and Deep Publications: New Delhi.

Madura, Jeff (2004), International Financial Management, $8^{\text {th }}$ Edition, Thomson: SouthWestern.

Miskin, Fredic S. (1984), “Are Real Interest Rates Equal Across Countries? An empirical Investigation of International Parity Conditions," Journal of Finance, vol. 39(5), pp.1345-1357, December.

Rahman, M. M. (2005), "Bangladesh-India Bilateral Trade: Causes of Imbalances and measures of Improvements," in working paper, University of Sydney, Australia.

Rogoff, K. (1996), “The Purchasing Power Parity Puzzle," Journal of Economic Literature, vol.34 (2), pp.647-668.

Shapiro, Alan C. (2003), Multinational Financial Management, $7^{\text {th }}$ Edition, John Wiley \& Sons Inc: India. 


\begin{tabular}{|l|c|c|c|c|}
\hline \multicolumn{4}{|c|}{ Table 1: Common Commodity Imports by Bangladesh from China and India } \\
\hline \multicolumn{1}{|c|}{ Group-wise Commodity } & \multicolumn{2}{c|}{$\begin{array}{c}\text { China (TK in } \\
\text { Millions) }\end{array}$} & \multicolumn{2}{c|}{$\begin{array}{c}\text { India (TK in } \\
\text { Millions) }\end{array}$} \\
\cline { 2 - 5 } & $\begin{array}{c}2005- \\
2006\end{array}$ & $\begin{array}{c}2004- \\
2005\end{array}$ & $\begin{array}{c}2005- \\
2006\end{array}$ & $\begin{array}{c}2004- \\
2005\end{array}$ \\
\hline Cotton,(all types) cotton yarn/thread and cotton fabrics & 2,987 & 2,072 & 2,284 & 1,246 \\
\hline Boilers, Machinery and mechanical appliances, parts thereof & 2,094 & 1,595 & 994 & 1,147 \\
\hline $\begin{array}{l}\text { Electrical machinery and equipment and parts thereof, sound recorders and } \\
\text { reproducers, television image and sound recorders and reproducers and } \\
\text { parts and accessories of such articles }\end{array}$ & & & & \\
\hline Man-made staple fibers & 1,334 & 636 & 323 & 302 \\
\hline Knitted or crocheted fabrics & 1,016 & 884 & 286 & 267 \\
\hline $\begin{array}{l}\text { Vehicles other than railway or tramway, rolling stock and parts and } \\
\text { accessories thereof }\end{array}$ & 857 & 665 & 91 & 93 \\
\hline Plastics and articles thereof & 214 & 200 & 704 & 504 \\
\hline Cereals & 164 & 98 & 474 & 444 \\
\hline
\end{tabular}

Source: Bangladesh Bank (2004-2005, 2005-2006), Import Payments (annual), Department of Public Relations \& Publication, Dhaka, Bangladesh.

\begin{tabular}{clrrrr}
\hline \multicolumn{7}{c}{ Table 2: Output for PPP Test (Data: 1978-2005) } & & \\
\hline Equation No. & Model & Coefficient & t-value & p-value & $\mathbf{R}^{2}$ \\
\hline PPP for BD with India & Constant & 1.602 & 7.70 & 0.000 & \\
& Ln $P_{t}$ (BD) & 0.604 & 2.00 & 0.056 & 0.76 \\
(Eq. \#2) & Ln $P_{t}^{*}$ (India) & -0.911 & -3.25 & 0.003 & \\
\hline PPP for BD with China & Constant & 3.438 & 14.5 & 0.000 & \\
& Ln $P_{t}$ (BD) & -0.529 & -2.13 & 0.043 & 0.63 \\
(Eq. \#2) & Ln $P_{t}^{*}$ (China) & 0.187 & 0.834 & 0.412 & \\
\hline
\end{tabular}

\begin{tabular}{ccccc}
\hline \multicolumn{5}{c}{ Table 3: Output for Unit Root Test (for 10 leg period) (Eq-4) } \\
\hline $\begin{array}{c}\text { Lag } \\
\text { Year }\end{array}$ & $\begin{array}{c}\text { ADF } \\
\text { BEER (BD/IN) }\end{array}$ & $\begin{array}{c}\text { ADF } \\
\text { BEER (BD/CH) }\end{array}$ & $\begin{array}{c}\text { ADF } \\
\text { Critical Value at 1\% }\end{array}$ & $\begin{array}{c}\text { ADF } \\
\text { Critical Value at 5\% }\end{array}$ \\
\hline 1 & -2.886 & -1.588 & -3.923 & -3.066 \\
2 & -2.104 & -1.619 & -3.923 & -3.066 \\
3 & -1.693 & -1.556 & -3.923 & -3.066 \\
4 & -1.779 & -1.821 & -3.923 & -3.066 \\
5 & -1.005 & -1.544 & -3.923 & -3.066 \\
6 & -1.303 & -2.032 & -3.923 & -3.066 \\
7 & -0.988 & -1.694 & -3.923 & -3.066 \\
8 & -0.613 & -1.381 & -3.923 & -3.066 \\
9 & -0.299 & -0.986 & -3.923 & -3.066 \\
10 & 0.022 & -0.4985 & -3.923 & -3.066 \\
\hline
\end{tabular}

\begin{tabular}{clrrrr}
\hline \multicolumn{7}{c}{ Table 4: Output for PPP Test (Data: 1978-2005) } & & \\
\hline Equation No. & Model & Coefficient & t-value & p-value & $\mathbf{R}^{\mathbf{2}}$ \\
\hline PPP for BD with India & Constant & 0.292 & 4.36 & 0.000 & 0.368 \\
(Eq. \#3) & Ln Pt (BD)/Ln Pt* (India) & 1.605 & 3.88 & 0.001 & \\
\hline PPP for BD with China & Constant & 1.965 & 23.12 & 0.000 & 0.035 \\
(Eq. \#3) & Ln P $(\mathrm{BD}) / \mathrm{Ln} \mathrm{Pt}^{\star}$ (China) & 0.321 & 0.966 & 0.343 & \\
\hline
\end{tabular}



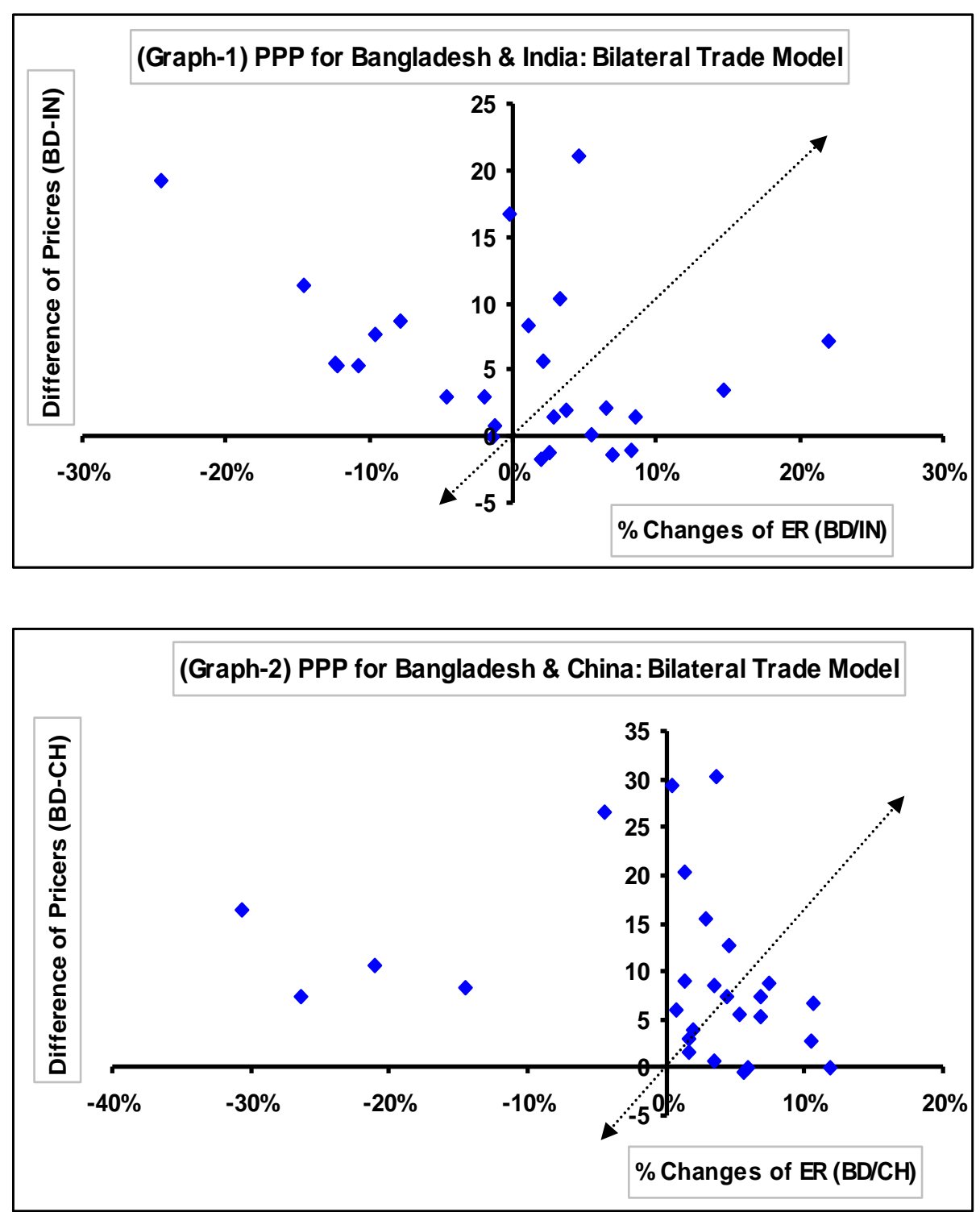